\title{
Growth and plant mass of radish fertirrigated with different doses nitrogen
}

\author{
Patrícia Ferreira da Silva ${ }^{1 *}$, Rigoberto Moreira de Matos², Vitoria Ediclecia Borges ${ }^{3}$, \\ Aryadne Ellen Vilar de Alencar ${ }^{4}$, José Dantas Neto ${ }^{5}$
}

10.1590/0034-737X201663020002

\begin{abstract}
The objective of the present study was to evaluate the effect of nitrogen doses applied via fertigation and associated with different types of crop establishment fertilization on growth and biomass of radish. The experiment was conducted in a greenhouse of the Academic Unit of Agricultural Engineering, Federal University of Campina Grande, from April to May 2014. Treatments consisted of five doses of nitrogen fertilizer applied by fertigation $(0,0.7,1.4,2.1$ and $2.8 \mathrm{~g}$ per pot $)$ and three types of crop establishment fertilization (humus 2:2; NPK and control), arranged in a $5 \times 3$ factor design with four repetitions. The 15 treatments were arranged in 60 plots. The nitrogen source used in the study was urea, divided in three applications: the first application was carried out eight days after transplanting, the second, on day 15 , and the third, on day 22. The crop establishment fertilization significantly influenced the growth variables and plant mass of the radish on day 35 after transplanting. The highest values of the variables (number of leaves, plant height, bulb diameter, leaf area, fresh mass of the aerial part, dry mass of the aerial part and root/aerial part were observed in the treatment with humus on day 35 after transplanting. The dose of $2.8 \mathrm{~g}$ nitrogen per pot corresponding to $6.22 \mathrm{~g}$ of urea per plant provided the highest yield for the variable number of leafs, leaf area and root length on day 35 after transplanting.
\end{abstract}

Key words: drip irrigation, greenhouse, humus, Raphanus sativus L., urea.

\section{RESUMO}

\section{Crescimento e fitomassa de rabanete fertirrigado com diferentes doses de nitrogênio}

Objetivou-se, com este estudo, avaliar o efeito de doses de nitrogênio, aplicadas por fertirrigação e associadas a diferentes tipos de adubação de fundação, sobre o crescimento e a fitomassa do rabanete. O experimento foi conduzido em casa de vegetação pertencente à Unidade Acadêmica de Engenharia Agrícola, Universidade Federal de Campina Grande, de abril a maio de 2014. Os tratamentos consistiram em cinco doses de adubação nitrogenada, aplicadas por fertirrigação ( $0 ; 0,7 ; 1,4 ; 2,1$ e 2,8g por vaso), e em três tipos de adubação de fundação (húmus 2:2; NPK e testemunha), arranjados em esquema fatorial 5 x 3 , com quatro repetições. Os 15 tratamentos foram dispostos em 60 parcelas; a fonte de nitrogênio utilizada foi a ureia, dividida em três aplicações: a primeira aos oito dias após o transplantio, a segunda aos 15 e, a terceira, aos 22. A adubação de fundação influenciou significativamente as variáveis de crescimento e a fitomassa do rabanete, aos 35 dias após o transplantio. Os maiores valores das variáveis (número de folhas, altura da planta, diâmetro do bulbo, área foliar, fitomassa fresca da parte aérea, fitomassa seca da parte aérea e relação raiz parte aérea) foram observados no tratamento com húmus, aos 35 dias após o transplantio. A dose de 2,8 g de nitrogênio por vaso, correspondente a 6,22 g de ureia por planta, foi a que proporcionou maior rendimento para as variáveis número de folhas, área foliar e comprimento da raiz, aos 35 dias após o transplantio.

Palavras-chave: ambiente protegido, húmus, irrigação localizada, Raphanus sativus L., ureia.

\footnotetext{
Received December 15th, 2014 and Accepted on October 15th, 2014

' Federal University of Campina Grande, Campina Grande, Paraíba, Brazil. patrycyafs@yahoo.com.br

${ }^{2}$ Federal University of Campina Grande, Campina Grande, Brazil. rigobertomoreira@gmail.com

Federal University of Campina Grande, Campina Grande, Brazil. edicleciaborges@gmail.com

${ }^{4}$ Federal University of Campina Grande, Campina Grande, Brazil. aryadne_ellen@ hotmail.com

${ }^{5}$ Federal University of Campina Grande, Campina Grande, Brazil. zedantas1955@gmail.com

Corresponding author: patrycyafs@yahoo.com.br
} 


\section{INTRODUCTION}

The radish (Raphanus sativus L.) is a small-sized brassicaceae whose most accepted cultivars produce globular bright scarlet roots and white pulp (Filgueira, 2008). The Brazilian production of radish is estimated at 10,489 tons, most of which produced in greenbelts of metropolitan areas on small farms of two to five hectares. In Brazil, there are approximately 7,353 units producing radish, out of which, about 352 units are located in the northeast region (IBGE, 2006).

One of the advantages of growing this species is the possibility of obtaining income from two other longer cycle crops because, besides being fairly rough, it has very short cycle (about 35 days), with rapid return (Cardoso \& Hiraki, 2001).

Nitrogen is an essential element for plants and its low availability in the soil, associated with plant uptake, limits vegetative growth in a drastic manner. It is a constituent of the amino acids, being necessary for the synthesis of chlorophyll, influencing the photosynthetic process (Marenco \& Lopes, 2009).

The deficiency of this nutrient may be responsible for reducing the quantity of assimilated generated during the carbon dioxide fixation process, reducing the availability of these compounds for reproductive organs. Although nitrogen is an important nutrient for vegetables, little is known about the amounts to be used in the radish crop (Quadros et al., 2010).

Besides being useful for plants since this nutrient is supplied along with water (essential for absorption), fertigation presents many other advantages, such as to improve the distribution of the fertilizer in the field and the possibility of greater fragmentation of fertilization, increasing the use efficiency of fertilizers by plants (Duenhas et al., 2002).

According to Quadros et al. (2010); Silva \& Silveira (2012); Cardoso \& Hiraki (2001) and Pedó et al. (2013), the application of fertilizers via irrigation water (fertigation) is a common practice for crops growing in a protected environment, which leads to better use of the irrigation system, providing a good cost / benefit relationship to the farmer.

Therefore, further studies that contribute to a proper management of nitrogen fertilization associated with the crop establishment fertilization, aimed at achieving high yields with minimal environmental impacts and without reducing crop growth are needed. Thus, the objective of this study was to evaluate the effect of nitrogen, applied by fertigation and associated with different types of crop establishment fertilization on growth and plant mass of the radish

\section{MATERIAL AND METHODS}

The experiment was conducted in a greenhouse of the Academic Unit of Agricultural Engineering, Federal University of Campina Grande, Campina Grande, State of Paraíba, from April to May 2014. The soil used in the experiment was classified as medium-texture sandy loam. The results of the analysis of the physical and chemical characteristics of the soil at a depth of $0.0-0.2 \mathrm{~m}$, are shown in Table 1, according to the methodology of EMBRAPA (2013).

The data on temperature and air relative humidity during the experimental period, from sowing to harvest, corresponded to 35 days, were collected from the set inside the greenhouse (Figure 1).

The treatments consisted of the combination of two factors: five doses of nitrogen fertilizer applied by fertigation $\left(0,50,100,150\right.$ and $200 \mathrm{mg}$ of nitrogen per $\mathrm{dm}^{3}$ soil), and three types of crop establishment fertilization (worm humus 2:2; NPK; soil without crop establishment fertilization). The source of nitrogen used was urea, and the levels of nitrogen per pot corresponded to $0 ; 0.7 ; 1.4$; 2.1 and $2.8 \mathrm{~g} \mathrm{~N}$ per pot, according to the methodology proposed by Silva \& Silveira (2012), divided into three applications: the first application was carried out on day 8 after transplanting (DAT); the second, on day 15 after transplanting, and the third, on day 22 after transplanting.

The statistical design used was a completely randomized block design with four replications, so that the studied factors were arranged in a 5 x 3 factor design. The 15 treatments were arranged in 60 plots, that is, 60 cylindrical pots of $12 \mathrm{~L}$ spaced by $0.5 \mathrm{~m}$ between plants and by $1.0 \mathrm{~m}$ between rows. Each experimental unit consisted of one pot with holes in the bottom, containing a 1-cm layer of gravel number 1, covered with geotextile blanket, to facilitate drainage. The pots were filled with approximately $14 \mathrm{dm}^{3}$ of soil.

The radish cultivar used in this study was Crimson Giant, one of the most cultivated in northeastern Brazil by small vegetable farmers. The seedlings were grown in expanded polyethylene trays with 128 cells filled with commercial substrate. Transplanting was carried out using two seedlings per pot, approximately eight days after sowing.

The experiment used the drip irrigation system with compensating type emitters, with a nominal flow rate of 2.3 $\mathrm{L} \mathrm{h}^{-1}$, coupled to irrigation lines (16-mm polyethylene tubes), with registers set at the beginning of each line , which allowed to differentiate by treatment, the application of nitrogen doses per fertigation, and a hydrometer at the beginning of the control drophead to record the amount of water per sideline, an indispensable condition for the control of irrigation and fertigation management. 
Pumping was performed with a centrifugal pump and to prevent the entry of suspended particles larger than the diameter of the emitters in the system, a 1 "screen filter", with capacity for $5 \mathrm{~m}^{3} \mathrm{~h}^{-1}$ flow was used.

Irrigation management was carried out by a two-day fixed irrigation and the water depth was obtained by crop evapotranspiration (ETc), from drainage readings in the lysimeters, which indicated the average balance of the entry and output of the water, keeping the humidity at values close to field capacity over the crop cycle, according to Equation 1.

$E T C=1-D$

Where,

$\mathrm{ETc}=$ crop evatranspiration, in $\mathrm{mm}_{\text {day }^{-1}} ; \mathrm{I}=$ irrigation depth applied at $\mathrm{mm} \mathrm{day}^{-1}$; and $\mathrm{D}=$ drainage depth in the lysimeter, at mm day ${ }^{-1}$.

On day 35 after transplanting (DAT) the following variables were analyzed: number of leaves per plant determined by counting the leaves of each plant; Plant height - measured by ruler graduated in centimeters from the ground base to the larger end of the plant; the bulb diameter - measured by digital caliper; leaf area-measured by Equation 2; root length; the fresh and dry mass of the aerial part and the root/aerial part relationship.
The plant fresh matter was measured using a digital scale, with three decimal places of precision in $\mathrm{g}$ and, after drying in a stove at $60^{\circ} \mathrm{C}$, the dry matter was determined.

$$
A F=C * L * f
$$

Where:

$\mathrm{AF}=$ leaf area, in $\mathrm{cm}^{2} ; \mathrm{C}=$ length, in $\mathrm{cm} ; \mathrm{L}=$ width, in $\mathrm{cm}$; and $\mathrm{f}=$ correction factor for radish, (0.57) dimensionless, according to the methodology proposed by Matos et al. (2015).

The variables were analyzed statistically by $\mathrm{F}$ test, unfolding the analysis whenever the interaction was significant. The quantitative factor concerning to doses of nitrogen, was statistically analyzed by means of polynomial regression (linear and quadratic) and the types of crop establishment fertilization using the Tukey test at $5 \%$, with the computer program Sisvar (Ferreira, 2008).

\section{RESULTS AND DISCUSSION}

The summary of the analysis of variance for the number of leaves (NL), plant height (PH), the bulb diameter (BD), leaf area (LA), root length (RL), fresh plant mass of the aerial part (FFPA), dry plant mass of the aerial part (DPMAP) and root/aerial part relationship (RR/AP) of radish plants under different crop establishment

Table 1: Physical and chemical characteristics of the soil used in the experiment, at the $0.0-0.2 \mathrm{~m}$ depth, Campina Grande, State of Paraíba

\begin{tabular}{|c|c|c|c|c|c|c|c|c|}
\hline \multirow[t]{2}{*}{ pH } & M.O & $\mathbf{P}$ & \multirow[t]{2}{*}{$\mathbf{K}$} & $\mathbf{N a}$ & $\mathrm{Ca}$ & Mg & Al & \multirow[t]{2}{*}{$\mathbf{H}$} \\
\hline & $(\%)$ & $\mathrm{mg} / 100 \mathrm{~g}$ & & \multicolumn{4}{|c|}{$\mathbf{m m o l}_{c} \mathbf{d m}^{-3}$} & \\
\hline \multirow[t]{4}{*}{5.9} & 0.65 & 1.43 & 0.14 & 0.07 & 1.9 & 0.66 & 0.2 & 1.88 \\
\hline & Density & & Sand & & Silt & & Clay & \\
\hline & $\left(\mathrm{g} \mathrm{cm}^{-3}\right)$ & & & & $(\%)$ & & & \\
\hline & 1.39 & & 74.7 & & 16.11 & & 9.19 & \\
\hline
\end{tabular}

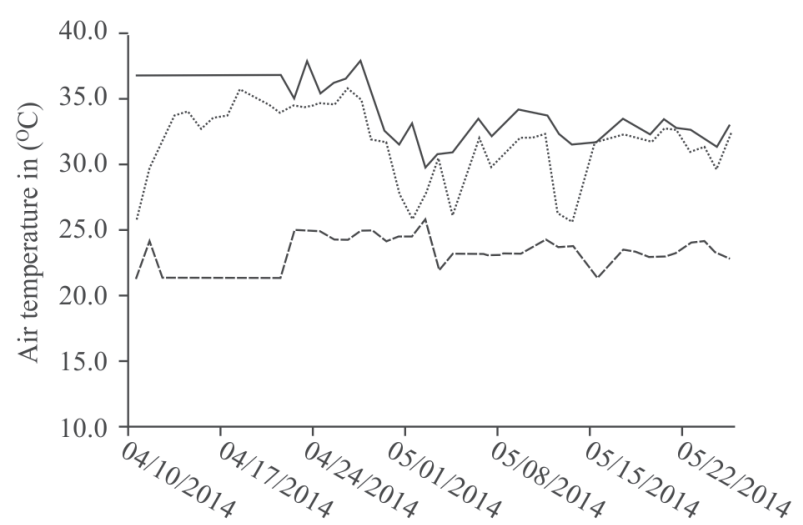

Collection dates

........... Instant - - Maximum Minimum

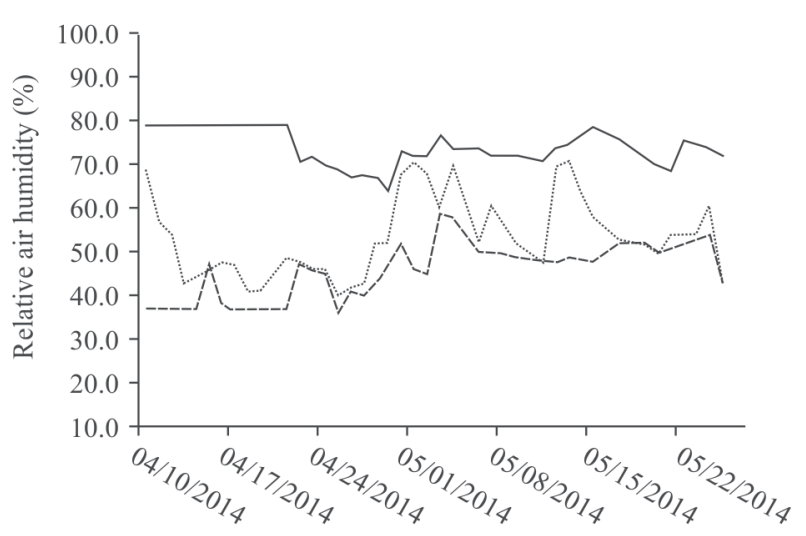

Collection dates

-........... Instant - Maximum ---- Minimum

Figure 1: Maximum and minimum (1A) instant air temperature, and maximum and minimum (1B) instant relative air humidity, during the trial period, Campina Grande, State of Paraíba.

Rev. Ceres, Viçosa, v. 63, n.2, p. 122-128, mar/abr, 2016 
fertilization and nitrogen levels applied by fertigation, 35 days after transplanting, is in table 2 .

It can be seen that the variables analyzed were significant at $1 \%$ of probability for factor fertilization, except for the length of the root. It was found for nitrogen fertigation factor a significant effect for the variable number of leaves, leaf area, root length, at 5 and $1 \%$, respectively. However, it was not found any significant effect of the interaction between types of fertilization (A) x nitrogen fertigation $(\mathrm{F})$ in radish crop on day 35 after transplanting (Table 2).

These results differ from those obtained by Quadros et al. (2010), who also worked with radish and $\mathrm{N}$ doses applied by fertigation, since they found that the doses of $\mathrm{N}$ did not interfere with the production of radish.

When studying radish crop fertigation with different doses of nitrogen $(0.0 ; 62.5 ; 125.0 ; 187.5$ and $200.0 \mathrm{~g} \mathrm{~N}$ $\mathrm{dm}^{-3}$ ) Silva \& Silveira (2012) concluded that the plant fresh mass of the aerial part (PFMAP), root fresh mass (RFM), dry mass of the aerial part (DMAP), root dry mass (RDM) and the root diameter of the radish (RD) did not show any statistical difference by the test of Tukey at $5 \%$, probably due to the nitrogen from the mineralization of soil organic matter and due to the inclusion of small dose of urea at sowing. These results are consistent with those obtained in this study, since variables fresh plant mass of the aerial part and dry plant mass of the aerial part were not influenced by the levels of nitrogen applied, by the test of Tukey at $5 \%$.

The number of leaves in function of crop establishment fertilization showed the best performance with NPK fertilizers and humus, when compared with the control, which contained only the nutrients found in the soil analysis (Figure 2A). Costa et al. (2006), when studying the growth and production of radish grown under different levels of humus of worm and cattle manure, stated that there was no difference between the effects of organic fertilizer sources on growth parameters, disagreeing with the findings of this study.

The number of leaves in function of the crop establishment fertilization performed better with fertilizations with NPK and humus, when compared with the control, which contained only the nutrients found in the soil analysis (Figure 2A). Costa et al. (2006), who studied the growth and radish production grown under different doses of worm humus and manure, stated that
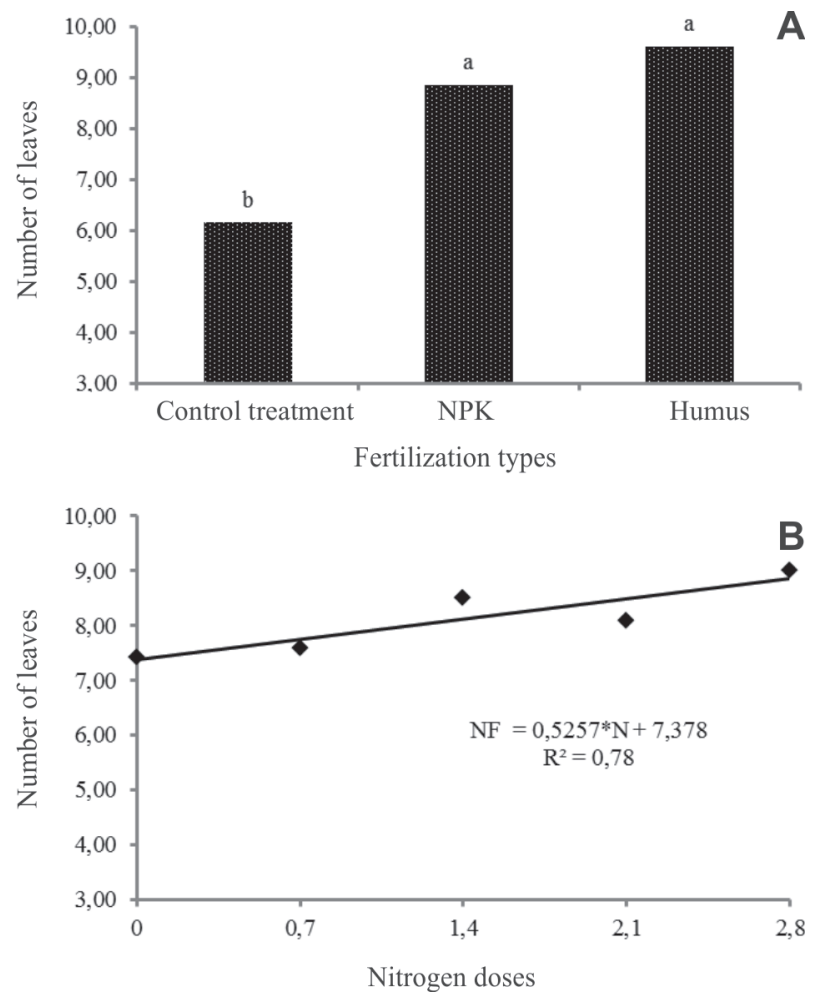

Figure 2: Number of leaves according to the types of fertilization (2A) and nitrogen doses per pot (2B) of radish, 35 days after transplanting, Campina Grande, State of Paraíba.

Table 2: Summary of the analysis of variance for leaf number (LN), plant height (PH), bulb diameter (BD), leaf area (LA), root length (RL), plant fresh mass of the aerial part (FFPA), plant dry mass of the aerial part (FSPA) and root/aerial part relationship of radish plants under different crop establishment fertilization and nitrogen doses applied via fertigation, 35 days after transplanting, Campina Grande, State of Paraíba.

\begin{tabular}{lccccccccc}
\hline \multirow{2}{*}{ Sources of Variation } & \multirow{2}{*}{ GL } & \multicolumn{8}{c}{ Values of Mean Squares } \\
\cline { 3 - 10 } & & NF & AP & DB & AF & CR & FFPA & FSPA & RR/PA \\
\hline Types of Fertilization (A) & 2 & $2.01^{* *}$ & $3.48^{* *}$ & $0.29^{* *}$ & $12026.38^{* *}$ & $0.31^{\text {ns }}$ & $60.12^{* *}$ & $16.83^{* *}$ & $0.13^{* *}$ \\
Nitrogen Fertigation (F) & 4 & $0.17^{*}$ & $0.09^{\text {ns }}$ & $0.08^{\text {ns }}$ & $655.91^{* *}$ & $0.47^{*}$ & $1.70^{\text {ns }}$ & $0.42^{\text {ns }}$ & $0.05^{\text {ns }}$ \\
Linear regression & 1 & $11.40^{*}$ & $3.13^{\text {ns }}$ & $1.80^{\text {ns }}$ & $15026650.75^{*}$ & $2.65^{\text {ns }}$ & $49.22^{\text {ns }}$ & $11.76^{\text {ns }}$ & $0.06^{\text {ns }}$ \\
Quadratic regression & 1 & $5.72^{\text {ns }}$ & $1.88^{\text {ns }}$ & $0.58^{\text {ns }}$ & $17139141.98^{*}$ & $1.29^{\text {ns }}$ & $520.60^{\text {ns }}$ & $1.75^{\text {ns }}$ & $0.09^{\text {ns }}$ \\
(A) x (F) interaction & 8 & $0.05^{\text {ns }}$ & $0.47^{\text {ns }}$ & $0.01^{\text {ns }}$ & $218.18^{\text {ns }}$ & $0.07^{\text {ns }}$ & $2.36^{\text {ns }}$ & $0.50^{\text {ns }}$ & $0.01^{\text {ns }}$ \\
Block & 3 & 0.05 & 0.26 & 0.08 & 419.49 & 0.25 & 4.02 & 0.60 & 0.08 \\
Residue & 42 & 0.05 & 0.24 & 0.03 & 129.72 & 0.25 & 1.40 & 0.35 & 0.06 \\
CV $(\%)$ & - & 7.94 & 11.38 & 10.95 & 17.38 & 13.52 & 19.62 & 24.53 & 9.05 \\
\hline
\end{tabular}

* e ** means 5 and $1 \%$ of probability, respectively; ${ }^{\text {ns }}$ means not significant 
there was no difference between the effects of organic fertilizer sources on growth parameters, disagreeing with the findings of this study.

The increase in the amount of nitrogen applied by fertigation increased significantly the number of radish leaves, being the highest yield found at the dose of $2.8 \mathrm{~g}$ nitrogen per pot, corresponding to 8.8 leaves per plant (Figure 2B). In turn, Quadros et al. (2010) observed that the average of leaves per plant was 21.16, much higher than that found in this work, which can be explained by the higher amount of nitrogen applied in their study.

According to Pedó et al. (2013), when studying nitrogen fertilization and its relationship to biometrics and the partition of assimilates in radish plants of the cultivar "Comprido de Ponta Branca", the number of leaves per square meter, regardless of the amount of nitrogen used, increased during the ontogeny of the plants, and the curves were obtained with a high coefficient of determination $\left(\mathrm{R}^{2}=0.99\right)$.

It was found that the height of the plant and the bulb diameter were significantly influenced by the crop establishment fertilization, 35 days after transplanting. It was observed that, for plant height, the effect of crop establishment fertilization with NPK did not differ statistically from the effect of fertilization with humus; however, when compared with the results obtained with the control, significant differences were found using the test of Tukey (Figure 3A).

With regard to the variable "bulb diameter", the effects of control and NPK treatments did not differ; nevertheless, when confronted with the effects of humus, significant differences were found (Figure 3B), which may have occurred because the control treatment presented a sufficient amount of nutrients to supply the crop demand.

Silva et al. (2006), in an experiment carried out with different amounts of worm humus and cattle manure incorporated in the crop establishment, found no influence of organic fertilization on radish crop for the variable diameter of roots, differing from the results found in this study, possibly due to the difference among the tested amounts of humus.

The different types of crop establishment fertilization differed statistically by the test of Tukey at $5 \%$ for the variable leaf area (Figure 4A). It was found that the treatment that provided the best results was the one with humus, followed by NPK treatment.

This fact might be related to the larger amounts of nitrogen present in the NPK treatment and humus. According to Araújo et al. (2013), the worm humus is admittedly rich in nitrogen, an essential element for plants, directly involved in vegetative growth, participating in the construction of chlorophyll molecule and protein.
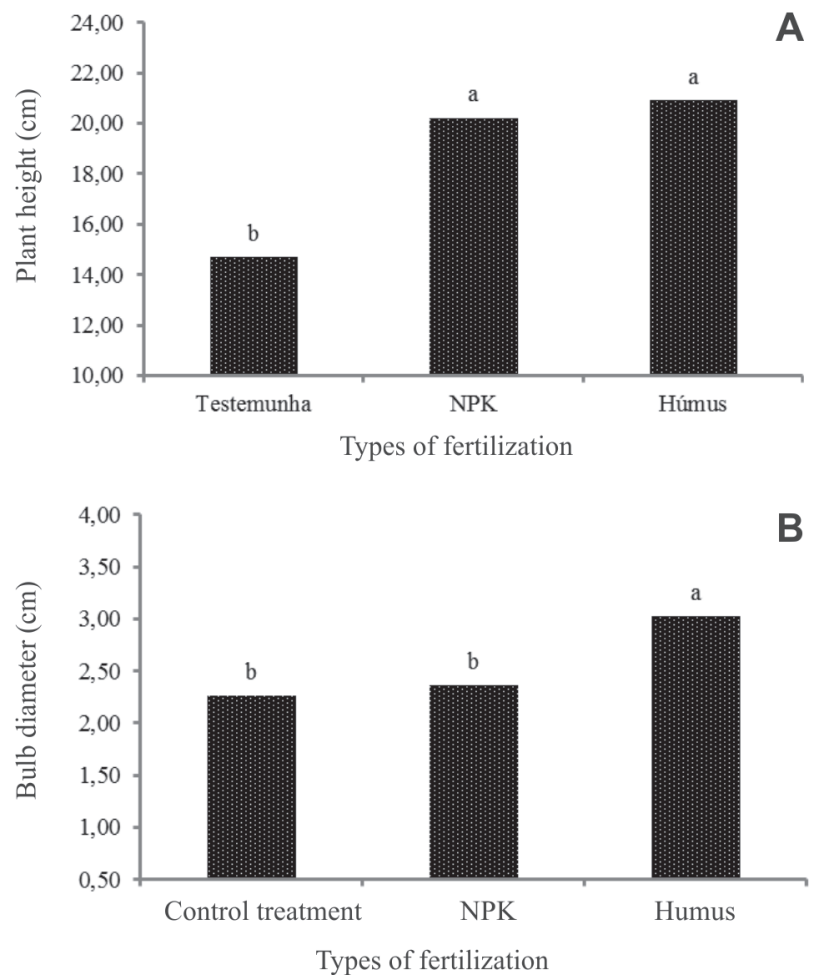

Figure 3: Plant height and diameter of the bulb according to the types of fertilization (3A and 3B) of radish 35 days after transplanting, Campina Grande, State of Paraíba.

A
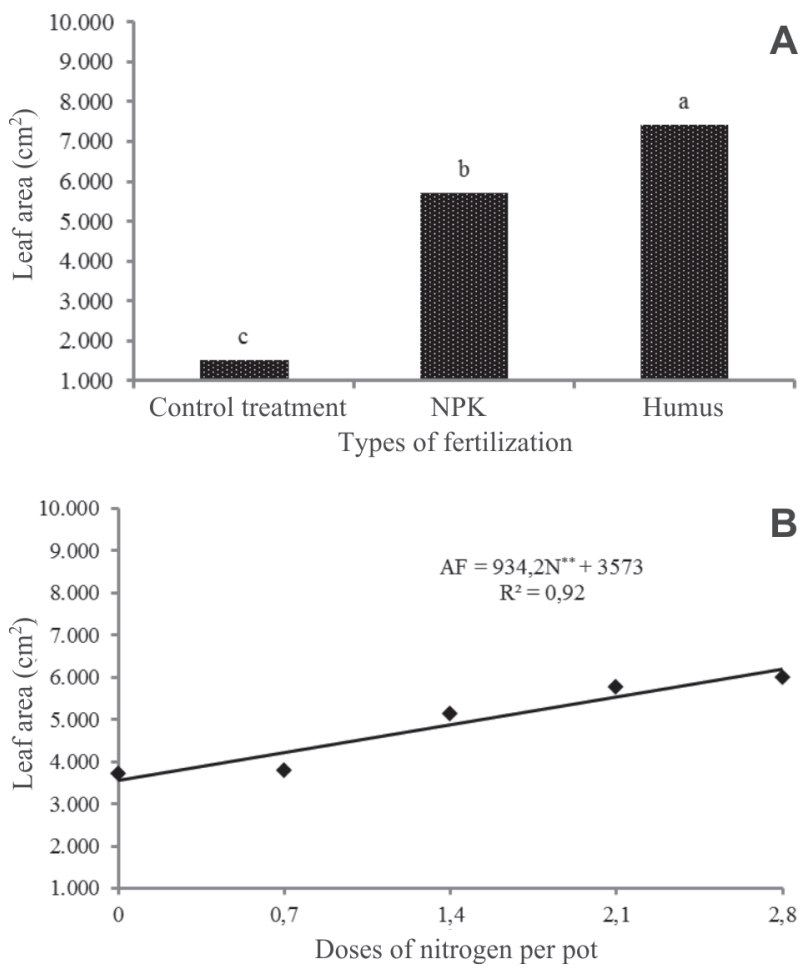

Figure 4: Leaf area according to the types of fertilization (4A) and according to the doses of nitrogen per pot (4B) of radish 35 days after transplanting, Campina Grande, State of Paraíba. 
The organic matter content in humus may have made nitrogen available for the radish plants, the reason why they responded better when compared to the responses from the other treatments (Quadros et al., 2010).

From the regression equation obtained, it was found that the leaf area of the radish increased as the amount of nitrogen increased which is the highest value for leaf area observed at a dose of $2.8 \mathrm{~g}$ nitrogen per pot (Figure 4B). Similar results for the leaf area were obtained for the radish by Robin \& Arenas (2006), when they studied the potential use in farming of organic products generated by water treatment, and by Teófilo et al. (2009), when they evaluated and quantified the growth of three carrot cultivars.

The linear mathematical model was the one that best fitted the root length, and, as the amount of nitrogen was increased, the value of the response variable was raised, being equivalent to the maximum root length obtained with the dose of $2.8 \mathrm{~g}$ nitrogen per pot (Figure $5 \mathrm{~A}$ ).

Cardoso \& Hiraki (2001), when studying doses and times for top-dressing calcium nitrate application in the radish crop, found that the doses did not affect the length of the roots when $\mathrm{N}$ doses $\left(100,200\right.$ and $300 \mathrm{~kg} \mathrm{ha}^{-1}$ ) was applied in the form of calcium nitrate 20 days after sowing, disagreeing with the results obtained in this study as significant differences between the effects of nitrogen rates on root length were found.

Significant differences were found for the variable plant fresh mass of the aerial part, in function of the types of crop
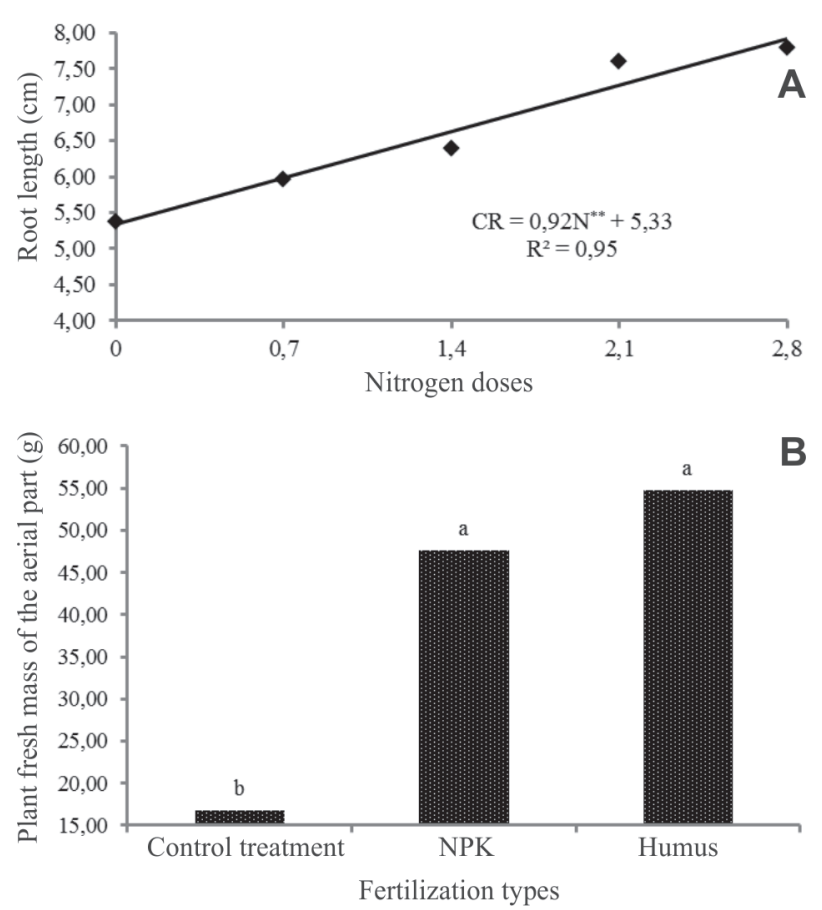

Figure 5: Root length in function of the nitrogen doses per pot $(5 \mathrm{~A})$ and in function of the fertilization types (5B) of radish 35 days after transplanting, Campina Grande, State of Paraíba. establishment fertilization; however, no significant difference among the effects of NPK and worm humus treatments was found, with the highest results achieved in the treatment with humus, corresponding to $54.8 \mathrm{~g}$ (Figure 5B).

When studying the production of organic radish with different sources of organic fertilizers, Souza et al. (2011) found that the treatments with worm humus provided lower plant fresh mass of the aerial part, contradicting the findings of this study, since the maximum result was obtained in the treatment with humus.

The plant dry mass of the aerial part was significantly influenced by the type of crop establishment fertilization. It is observed that the means of the plant dry mass of the aerial part were not statistically different in the NPK treatments and with húmus, where the highest mean was $9.8 \mathrm{~g}$, significantly different from the mean in the control treatment (Figure 6A).

Silva \& Silveira (2012), when studying different amounts of nitrogen in radish crop, achieved different results from the ones found in this study, since the dry matter of the aerial part did not differ statistically by the test of Tukey and its highest means was $6.8 \mathrm{~g}$, lower than that found in this work.

The root/aerial part relationship was influenced by the type of crop establishment fertilization and the means of the root/ aerial part relationship resulting from the control and the NPK treatments did not differ from each other, being lower than that obtained by using humus, in which
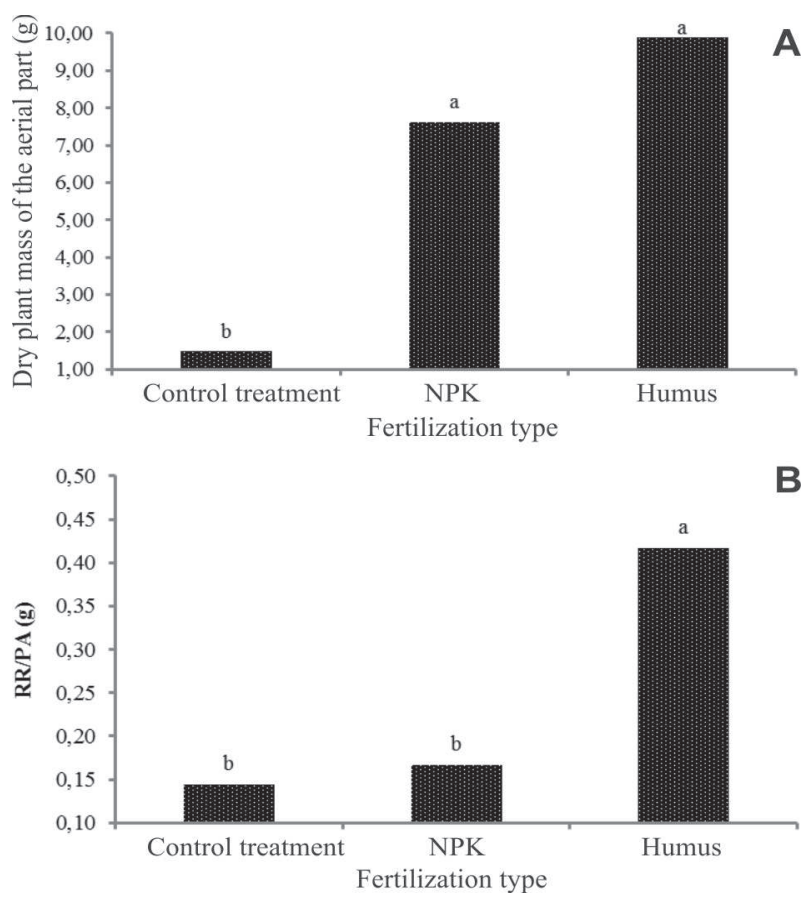

Figure 6: Dry plant mass of the aerial part and root/aerial part ratio in function of the fertilization types $(6 \mathrm{~A}$ and $6 \mathrm{~B})$ of the radish 35 days after transplanting, Campina Grande, State of Paraíba. 
the highest value obtained in this treatment corresponded to $0.41 \mathrm{~g}$ (Figure 6B). Consistent results were observed by Silva et al. (2015) when studying harvest index and assimilated partition of radish under nitrogen fertigation and crop establishment fertilization.

\section{CONCLUSIONS}

The crop establishment fertilization significantly influenced the variables growth and plant mass of radishes 35 days after transplanting.

The highest values of the variables number of leaves, plant height, bulb diameter, leaf area, plant fresh mass of the aerial part, plant dry mass of the aerial part and root/ aerial part relationship were observed in the treatment with humus, 35 days after transplanting.

The nitrogen dose of $2.8 \mathrm{~g}$ per pot, corresponding to $6.22 \mathrm{~g}$ of urea per plant, was the one that provided the highest income for the variable number of leaves, leaf area and root length at 35 days after transplanting.

\section{REFERENCES}

Araújo AC, Araújo AC, Dantas MKL, Pereira WE \& Aloufa MAI (2013) Utilização de substratos orgânicos na produção de mudas de mamoeiro Formosa. Revista Brasileira de Agroecologia, $8: 210-216$.

Cardoso AII \& Hiraki H (2001) Avaliação de doses e épocas de aplicação de nitrato de cálcio em cobertura na cultura do rabanete. Horticultura Brasileira, 19:328-33.

Costa CC, Oliveira CD, Silva CJ, Timossi PC \& Leite IC (2006) Crescimento, produtividade e qualidade de raízes de rabanete cultivadas sob diferentes fontes e doses de adubos orgânicos. Horticultura Brasileira, 24:118-122.

Duenhas LH, Villas Bôas RL, Souza CMP, Ragoso CRA \& Bull LT (2002) Fertirrigação com diferentes doses de N P K e seus efeitos sobre a produção e qualidade de frutos de laranja (Citrussinensis O.) 'Valência'. Revista Brasileira de Fruticultura, 24:214-218.

EMBRAPA - Empresa Brasileira de Pesquisa Agropecuária (2013) Sistema brasileiro de classificação de solos. Rio de Janeiro, EMBRAPA. 412p.

Ferreira DF (2008) Sisvar: Sistema de análise de variância versão 4.6. Lavras, UFLA/DEX. CD-ROM.

Filgueira FAR (2008) Novo manual de olericultura: Agrotecnologia moderna na produção e comercialização de hortaliças. Viçosa, UFV. $421 \mathrm{p}$.

IBGE - Instituto Brasileiro De Geografia E Estatística (2006) Censo agropecuário. Disponível em: <http://www.ibge.gov.br/ home/ estatistica/economia/agropecuaria/censoagro/ brasil_2006/Brasil_censoagro2006.pdf>. Acessado em: 21 de julho de 2015.

Marenco RA \& Lopes NF (2009) Fisiologia vegetal: fotossíntese, respiração, relações hídricas e nutrição mineral. $3^{\mathrm{a}}$ ed. Viçosa, UFV. 468p.

Matos RM, Silva PF, Lima SC, Santos CS \& Dantas Neto J (2015) Características foliares e índice de colheita do rabanete irrigado com água residuária em ambiente protegido. Enciclopédia Biosfera, 11:372-386.
Pedó T, Martinazzo EG, Aumonde TZ, Cappellari MR, Souza VL, Souza EA, Villela FA, Lopes NF \& Mauch CR (2013) Adubação nitrogenada e sua relação à biometria e partição de assimilados em plantas de rabanete cultivar comprido de ponta branca. Tecnologia \& Ciência Agropecuária, 7:31-36.

Pisco RR \& Arenas MIP (2006) Evaluaciondel potencial de losbiosólidos procedentes deltratamiento de aguas residuales para uso agrícola y suefecto sobre el cultivo de rabano rojo (Raphanus sativus L.). Revista Facultad Nacional de Agronomía, 59:35433556 .

Quadros BR, Silva ES, Borges LS, Moreira CA, Moro AL \& Villas Bôas RL (2010) Doses de nitrogênio na produção de rabanete fertirrigado e determinação de clorofila por medidor portátil nas folhas. Irriga, 15:353-360.

Silva CJ, Timossi DC \& Leite PC (2006) Crescimento e produção de rabanete cultivado com diferentes doses de húmus de minhoca e esterco bovino. Revista Ceres, 53:25-30.

Silva CRM \& Silveira MHD (2012) Fertirrigação da cultura do rabanete com diferentes dosagens de nitrogênio. Enciclopédia Biosfera, 8:946-953.

Silva PF, Matos RM, Dantas Júnior GJ, Alencar AEV \& Dantas Neto J (2015) Índice de colheita e partição de assimilados do rabanete sob fertirrigação nitrogenada. Enciclopédia Biosfera, 11:1176-1190.

Souza MDB, Nascimento AD, Ramos AB, Marques ND \& Silva RF (2011) produção orgânica de rabanete sob diferentes fontes de adubos orgânicos. Revista verde de agroecologia e desenvolvimento sustentável, 6:1-4.

Teófilo TMS, Freitas FCL, Negreiros MZ, Lopes WAR \& Vieira SS (2009) Crescimento de cultivares de cenoura nas condições de Mossoró-RN. Revista Caatinga, 22:168-174. 